\title{
AVÓS E NETOS: AS REPRESENTAÇÕES DA VELHICE NA LITERATURA INFANTIL DE LÍNGUA PORTUGUESA
}

\author{
GRANDPARENTS AND GRANDCHILDREN: REPRESENTATIONS OF \\ ELDERLY IN CHILDREN'S LITERATURE PUBLISHED IN PORTUGUESE
}

Renata Junqueira de Souza ${ }^{1}$

Jéssica Amanda de Souza Silva²

Clara Cassiolato Junqueira ${ }^{3}$

\begin{abstract}
Resumo: Este artigo objetiva investigar e comparar as representações do idoso e das relações intergeracionais entre avós e netos em dois livros literários, um brasileiro - Vó, para de fotografar!, de Ilan Brenman (2018) - e outro português - O meu avô, de Catarina Sobral (2014). Analisou-se: (1) as descrições das personagens idosas e crianças; (2) a relação intergeracional dessas personagens; (3) a configuração dos elementos afetivos; e (4) as similitudes entre às representações do idoso e das relações intergeracionais.
\end{abstract}

\begin{abstract}
This article aims to investigate and compare the representations of elderly and intergenerational relationships between grandparents and grandchildren in two illustrated children's book, a Brazilian one - Vó, para de fotografar!, by Ilan Brenman (2018) - and a Portuguese - O meu avô, by Catarina Sobral (2014). We analyzed: (1) the descriptions of the elderly characters and children; (2) the intergenerational relationship of these characters; (3) the configuration of the affective elements; and (4) the similarities between the books concerning the representations of the elderly and intergenerational relations.
\end{abstract}

Palavras-chave: Livro ilustrado; Envelhecimento; Idoso; Relação intergeracional; Literatura Infantil.

Keywords: Illustrated book; Aging; Elderly; Intergenerational relationship. Children's literature.

\section{Introdução}

As relações familiares sempre estiveram presentes em livros de literatura infantil. São diálogos entre pais e filhos, irmãos e, também, entre avós e netos, mesmo que essas figuras estejam metamorfoseadas em animais, como em Cachinhos Dourados e os três ursos, em que uma família "tradicional" é representada por ursos. Essa mesma representação de família é vista em outros contos, a exemplo de Chapeuzinho Vermelho, no qual o leitor tem contato com, talvez, a primeira idosa das histórias infantis universais: a vovozinha.

Esse agregado familiar, avô ou avó, é reconhecido em várias obras, desde o início da literatura

1 Universidade Estadual Paulista - Livre Docente

2 Universidade de Aveiro - Doutoranda - Pesquisa: Uma leitura comparada das representações do idoso na literatura infantil brasileira e portuguesa

3 Universidade Estadual Paulista - Mestranda - Pesquisa: Escola e leitura: a literatura infantil na construção da humanização da criança 
para crianças até a contemporaneidade. É imprescindível considerar, entretanto, que o conceito de família e os papéis desempenhados por seus membros não são histórica e socialmente fixos (PRADO, 2017). Pelo contrário, o que se verifica é que, nas últimas décadas, o referido conceito vem sendo academicamente repensado e ampliado em função das mudanças ocorridas nas estruturas familiares durante o tempo.

A literatura, por sua vez, especialmente a infantil contemporânea, acompanha essa tendência, ao trazer diferentes representações de núcleos familiares, de seus integrantes e das relações que se estabelecem entre os seus membros. A personagem idosa, também mudou, está, como veremos nesse artigo, mais ativa e mais próxima afetivamente dos seus netos. Assim, essas modificações ocorridas em razão de condições históricas, socioculturais e econômicas atribuem ao velho, um lugar simbólico, na medida em que sua função se diversifica entre os vários livros infantis em que avós e netos convivem. A amplitude da personagem pode ser percebida em obras para a infância, assim pretendemos nesse artigo, traçar o perfil do idoso retratado em textos literários de língua portuguesa.

Para tanto, esperamos inicialmente enfatizar o papel dos avós na literatura infantil, para, em seguida, discutir e analisar dois livros cujos protagonistas são avós. As obras selecionadas foram escritas em português, mas em continentes diferentes: o primeiro avô é português; o segundo, brasileiro, e trata de uma avó. Ambos trazem uma representação positiva da velhice, permitindo à criança leitora olhar para a pessoa idosa de maneira afetuosa e otimista, podendo contribuir para ações e posturas valorativas desse público.

\section{0 idoso nas literaturas infantis de língua portuguesa}

Na literatura infantil, especificamente, temos por vezes a reprodução de um perfil de velho ranzinza e "reclamão", que é caricaturado em personagens de diversos gêneros, como os contos de fada, desenhos animados, gibis etc., a exemplo do Tio Patinhas, idoso e ranzinza que, segundo Mendes (2012), é mal-humorado e se incomoda com a juventude e alegria alheias.

A representação do idoso aborrecido e teimoso, na literatura, pode ser tomada como uma verdade pela criança. Ela pode generalizar esse perfil a todos os velhos. É por isto que, na infância, a transmissão dessa representação estereotipada do idoso é ainda mais preocupante, pois é durante essa fase que conceitos e valores estão sendo construídos na percepção e no imaginário infantil, contribuindo para posturas e ações preconceituosas no decorrer de toda sua vida e contrariando o caráter humanizador da literatura.

Por outro lado, há, também, a reprodução de uma imagem dignificante do velho, a exemplo das personagens Gepeto (da obra Pinóquio, de Carlo Collodi) e Dona Benta (da obra A menina do narizinho arrebitado, de Monteiro Lobato). Em ambas as obras, as personagens idosas são 
descritas respeitosamente como experientes e sábias. Nas tramas, as relações criadas entre jovens e idosos são "saudáveis", em que o amor, o respeito e o cuidado são a fórmula para a boa convivência intergeracional. Acreditamos ser este o tipo de representação que, quando levada às crianças, através do livro infantil, contribui para a sua sensibilização.

Vários pesquisadores (FERNANDES, 2013; SILVEIRA, 2012) mencionam a função da pessoa velha como contadora de histórias e retentora de conhecimento. Neste sentido, Eclea Bosi (1994) afirma que a função social da velhice é a de lembrar. Para a autora, há uma construção nas narrativas de que os idosos não são ativos. Isso significa que os velhos, tem uma nova função social - lembrar e contar para os mais novos a sua história, de onde vieram, o que aprenderam e fizeram durante a vida.

Essa memória é verificada de várias maneiras por estudiosos da literatura infantil. Alguns idosos rememoram histórias de sua infância, de seu tempo ou ainda de suas origens. Ou seja, é o avô ou a avó, o narrador de acontecimentos e casos.

$\mathrm{Na}$ literatura infantil brasileira, poderíamos ilustrar esse tipo de velho trazendo à tona várias personagens e autores, mas sem dúvida as mais representativas são as de Monteiro Lobato, conhecidas pelos adultos através da extensa obra do autor e pelas crianças, pelos capítulos televisivos ou desenhos animados propagados pelos meios de comunicação, a partir dos textos literários. Dona Benta e Tia Nastácia, ambas idosas e moradoras do Sítio do Picapau Amarelo são exemplos de uma memória utilizada para a aproximação com os netos. Dona Benta é descrita como uma velha de mais de 60 anos, que fica na varanda com cestinha de costura no colo e óculos de ouro na ponta do nariz. É feliz, "a mais feliz das vovós, porque vive em companhia da mais encantadora das netas - Lúcia, a menina do nariz arrebitado, ou Narizinho como todos dizem.” (LOBATO, 2009, p. 12). Já a tia Nastácia, no livro Histórias de Tia Nastácia, tem seu nome e função atribuídos ao folclore:

Folclore são coisas que o povo sabe por boca, de um contar para o outro, de pais a filhos - os contos, as histórias, as anedotas, as superstições, as bobagens, a sabedoria popular etc. e tal. [...] Tia Nastácia é do povo. Tudo que o povo sabe e vai contando de um para o outro, ela deve saber. Estou com o plano de espremer tia Nastácia para tirar o leite de folclore que há nela. (LOBATO, 1956, p. 3)

As descrições e papeis desempenhados por essas duas idosas convergem para algumas definições da função do velho na sociedade. Pois, enquanto Dona Benta, conta histórias de mitos gregos e romanos, ou mesmo discute uma notícia de jornal, utilizando suas experiências e conhecimentos, tia Nastácia narra contos populares incluindo contos de origem africana e se referencia a todo momento, à vivências prévias, essas mais relacionadas com um imaginário coletivo, que cuida do outro com receitas caseiras e divulga uma cultura popular, superstições e até mesmo ditos e provérbios difundidos pela oralidade do povo. Da mesma maneira, um conhecido escritor português, José Jorge Letria, em 2008, escreveu o livro: Avô, conta outra vez. Trata-se de uma obra em que o avô conta histórias para 
o neto, histórias do seu mundo, de suas brincadeiras, em um tempo sem celular, sem internet e sem asfalto na rua. Há, no livro, pela voz do narrador idoso, o resgate do ficar em família, em aprofundar as relações familiares através do ato de contar (avô) e ouvir (neto) histórias.

\author{
Tenho em casa um saco cheio \\ De histórias para te contar \\ E só ando a fazer tempo \\ Para as poder escutar.
}

São histórias de outros tempos

Que a minha avó me contou

Com fadas e lobisomens

Que a imaginação guardou (LETRIA, 2008, s/n)

O mote "conta outra vez" é sempre utilizado pela criança que aprende com as histórias do avô e o texto compartilha a conquista progressiva da autonomia, o conhecimento do mundo, a partilha de uma memória, a continuidade das gerações, a ternura e o carinho, e, finalmente, a expressão sublime da saudade.

Essa mesma perspectiva, do idoso compartilhar suas histórias e as de seu povo, nos é dada por Sylviane A. Diouf (2004) no texto literário As tranças de Bintou. Nele, Bintou, uma menina africana está bastante decepcionada com seus quatro birotes na cabeça e não entende porque tem que crescer para ter tranças. É então, com a chegada da avó Soukeye, que a história das tranças de Coumba é narrada à neta.

Há muito tempo, existiu uma menina chamada Coumba que só pensava no quanto era bonita”, Vovó diz enquanto afaga minha cabeça. "Todos a invejavam, e ela foi se tornando uma menina vaidosa e egoísta. Foi nessa época, e por isso, que as mães decidiram que as crianças não usariam tranças, só birotes, porque assim elas ficariam mais interessadas em fazer amigos, brincar e aprender. (DIOUF, 2004, s/n)

No decorrer da narrativa, Bintou não consegue suas tranças, mas entende, através de um sonho, o rito de passagem da infância para a idade adulta. Nesse sonho, ela vê pássaros azuis e amarelos e no dia seguinte ganha da avó um cabelo muito especial. Há, na última página do livro, uma declaração de Bintou que se aceita como é, sentindo-se amada e conformada com a infância e com o tempo das coisas.

Como podemos verificar nesses exemplos, há portanto, uma socialização de saberes entre 
avós e netos, que se estabelece pela troca de experiências e se origina da cultura oral de um povo e é rememorada pelo mais velho, que também ensina o ente familiar mais jovem. Para Fox e Girardello (2008, p. 122), "a narrativa falada exerce poder sobre as crianças - elas querem a história, e querem ouvi-la bem contada, sem distrações.".

Nas narrativas mencionadas, o idoso assume a figura de um narrador que dividirá sua memória com os mais novos. Assim, percebemos que toda a memória e identidade coletiva eram armazenadas e conduzidas a gerações futuras por intermédio da fala desses narradores, mais velhos. Os contos tradicionais, cuja origem parece encontrar-se nos mitos primitivos, que por muitos séculos orientaram os homens em sua busca de conhecimento do cosmo e de si mesmos, não são obra de um só autor; resultam da produção coletiva de um povo que os cria a partir das representações do seu imaginário coletivo e, ao mesmo tempo, encontra neles o alimento para nutrir esse mesmo imaginário (MATOS, 2005, p. 2).

Dessa maneira, considerando que muitos livros infantis trazem representações diversas e dignificantes do idoso em suas páginas - distanciando-se cada vez mais de tendências estereotipadas ou desvalorativas em torno dessa fase da vida - acreditamos na relevância das investigações qualitativas, especialmente em close reading (CULLER, 2012) ${ }^{4}$, de obras infantis que apresentem o idoso de forma interativa e crédula, como é o caso do corpus selecionados para este estudo. Nesse sentido, pretendemos analisar, a seguir, dois livros escritos em português, cujos protagonistas são avós: o primeiro avô é português; a segunda, uma avó brasileira. Ambas as obras trazem uma representação positiva do velho, permitindo à criança olhar para a pessoa idosa de maneira assertiva e, por isso, contribuindo para ações e posturas valorativas desse público.

\section{Portugal}

O livro O meu avô (SOBRAL, 2014) apresenta técnicas muito modernas em design, ilustração e, consequentemente, representação das personagens. Assim, como se evidencia na sua leitura, a experiência literária também avança e é enriquecida ao adquirir novas possibilidades de apreensão de sentidos. A capa (fig. 1) apresenta um homem (ilustrado da cintura para baixo) e um garotinho, de mãos dadas:

4 "Leitura atenta", em tradução livre, é um método de análise utilizado em investigações de cunho qualitativo e corpus reduzido, entretanto minucioso e exaustivo, que permite observar criteriosamente a presença e configuração de determinado tema ou especificidade em cada obra constituinte do estudo. 


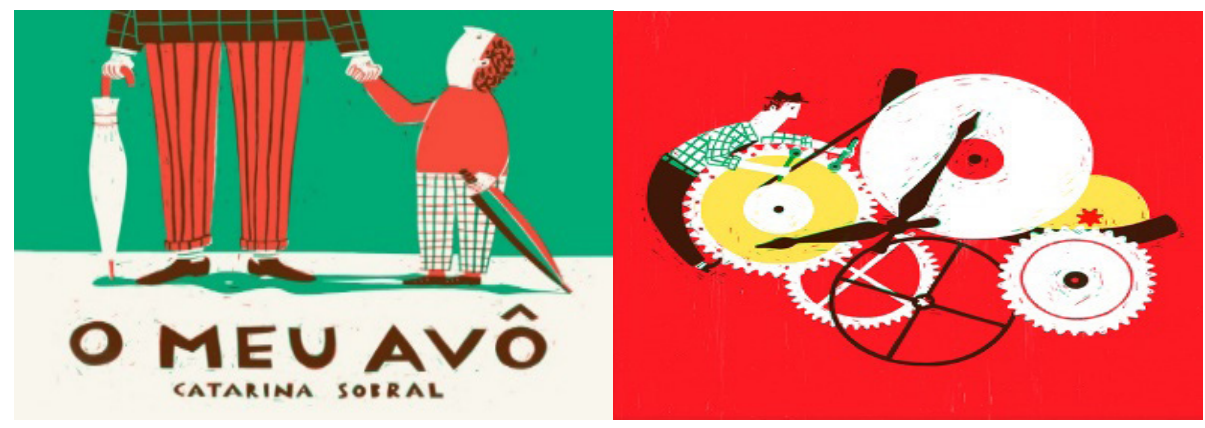

Figura 1 - Capa e contracapa de $O$ meu avô (2014)

Andar de mãos dadas pode significar parceria e/ou tutela. Essa última hipótese torna-se ainda mais possível ao percebermos que as pessoas representadas na imagem correspondem a um adulto e uma criança. O menino tem o corpo voltado para o homem, como se a ele respondesse, e o olha de queixo levantado, com ar de admiração. As suas sombras se abraçam no chão, sugerindo a inferência de uma relação afetiva, a confirmar-se ou refutar-se durante a leitura. O cenário que rodeia as personagens é verde e os detalhes das roupas, em contraste, são vermelhos (ambas cores primárias).

Já a contracapa (fig. 1) tem o fundo vermelho - que, além da "tragédia", representa ambientes agitados (BOON \& DAIN, 2015) - e retrata um homem ruivo, de vestes com detalhes verdes. Esse jogo cromático acompanha toda a obra, pois as referidas cores são predominantes e alternam-se inúmeras vezes. O homem, ilustrado na contracapa, que aparenta ter meia-idade, está consertando o que parece ser a parte mecânica de um relógio (os ponteiros indiciam esta hipótese). A partir das pistas da capa e contracapa, o leitor se questiona e tece inferências: homem e criança são avô e neto? $\mathrm{O}$ "tempo" será o principal tema?

$\mathrm{Na}$ folha de rosto, as mesmas personagens caminham de mãos dadas, de costas para o leitor, em convite para que os siga e aprecie as próximas páginas. O neto-narrador inicia a história com a descrição da rotina matinal do avô em comparação com a de outra personagem, o Dr. Sebastião. $\mathrm{O}$ discurso narrativo evidencia o tempo e o ritmo da obra é orientado pela disposição das atividades cotidianas, desenvolvidas pelos parentes em um único dia, em contraste com as atividades do vizinho, o Dr. Sebastião - única personagem retratada pelo nome, em lugar do grau de parentesco que referencia o avô e o neto. Assim como a ilustração (fig. 2) se vale de um paralelismo icônico, retratando os ambientes através de uma mesma perspectiva, que apresenta, de um lado, o avô e, do outro, o Dr. Sebastião -, a narrativa utiliza o paralelismo gramatical para sugerir essa diferença: de um lado da folha, "O meu avô acorda todos os dias às 6 da manhã"; do outro, "O Dr. Sebastião acorda às 7". 


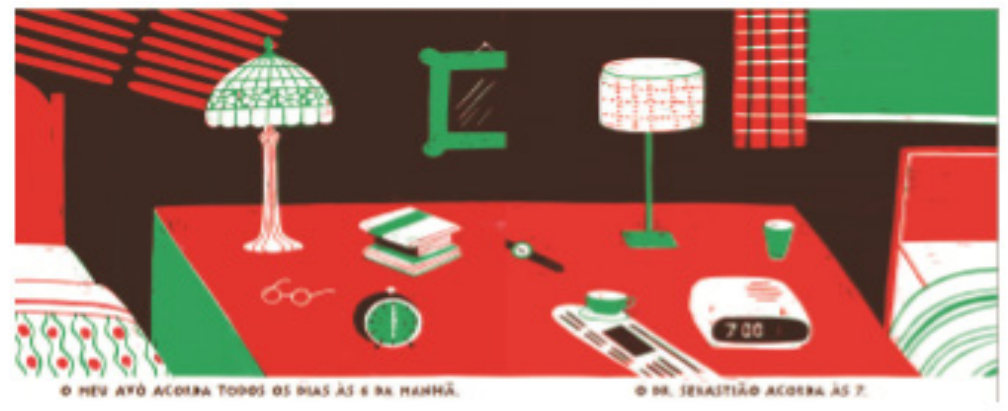

Figura 2 - O cotidiano do avô

Além do horário em que acordam, os objetos em cima de cada uma das mesinhas de cabeceira também propõem, simbolicamente, diferenças entre as personagens, instigando a imaginação e a curiosidade do leitor. Do lado esquerdo, no quarto do avô, há um óculos, um relógio analógico e livros. Já a mesinha do Dr. Sebastião apoia um relógio de pulso, um relógio digital, jornais, xícara e copo. Além das idades, esses objetos indicam ainda diferentes estilos de vida (pelas especificidades de cada objeto).

Para a criança leitora, esses detalhes não passam despercebidos, pois os seus olhos trabalham como um escâner durante a leitura; rondam toda a página, focam no que julgam importante, juntam peças como num quebra-cabeças, analisando o fundo e outros detalhes, "movem-se (ainda) para frente e para trás, entre palavras e imagens, relacionando umas às outras para entender, confirmar ou negar hipóteses acerca do que está acontecendo na história (ARIZPE \& STYLES, 2016, p. 97) 5. A ilustração (fig. 2) permite o uso dessas estratégias de leitura em que o leitor procura, na relação palavra e imagem, as peças (ou inferências) a fim de montar um quebra-cabeça (sentido).

A quantidade de relógios pertencentes ao Dr. Sebastião indica a importância do tempo cronológico para ele. O jogo cromático acompanha praticamente todas as ilustrações da obra, sugerindo o movimento e a agitação das atividades diárias. Outro indício desse preenchimento de tempo é a extensão das ilustrações em demasiadas e diferentes formas geométricas que se contrapõem de um lado e de outro da página, mas que se combinam, por sua simetria, não deixando espaços para os vazios.

As imagens seguintes (fig. 3) dão conta de ilustrar que o avô e o Dr. Sebastião "cruzam-se todos os dias à mesma hora", tratam-se com respeito e seguem às suas atividades. O jogo icônico faz com que o leitor deseje voltar a página e passá-la adiante repetidas vezes, a fim de visualizar o encontro e o afastamento das personagens. Segundo Colomer, Kümmerling-Meibauer e Silva-Díaz (2010, p. 116, tradução nossa) os livros ilustrados “[ ... nos permitem usar o avanço e a repetição, como assistir a um DVD, a fim de observar cuidadosamente qualquer detalhe que possamos ter perdido enquanto tentamos ter um completo entendimento do enredo na primeira leitura ${ }^{6}$ ".

5 Passagem original: "The eyes move back and forth between the words and images, leaning on each other for understanding, confirming or denying hypothesis about what is happening in the story" (ARIZPE \& STYLES, 2016, p. 97)

6 Passagem original: "allow us to use fast-forward and replay, like watching a DVD at home, in order to look carefully at any detail we might 

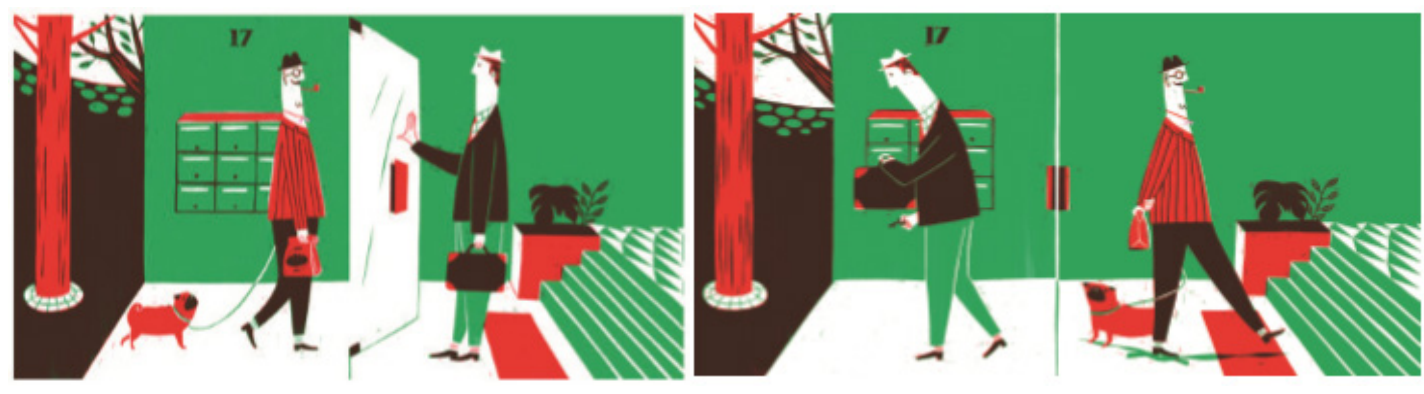

Figura 3 - O jogo icônico

A comparação entre o avô e o Dr. Sebastião é sustentada pela temática do tempo, pelo jogo icônico (fig. 3) e pelo jogo linguístico antagônico (CARDOSO, 2017): "O meu avô costumava ter uma loja de relógios. Agora tem bastante tempo" e "O Dr. Sebastião não é relojoeiro (apesar de estar sempre a ver as horas) e nunca tem tempo a perder". O bom aproveitamento do tempo é o que difere o avô do Dr. Sebastião, apesar de o primeiro já ter sido parecido com o segundo, nas palavras do neto: “Têm pouco em comum, embora o meu avô diga que já foi muito parecido com o Dr. Sebastião...".

Analisando o texto visual, verificamos uma dicotomia: apesar de fazer-se notar que as personagens adultas vivem num tempo cronológico igual e comum a ambos, o que se nota, num segundo momento, através das imagens - e somente delas - é que ambos vivem num tempo psicológico (que diz respeito à qualidade do tempo vivido) diferente, desvelando sentidos que vão muito mais além do que o texto nos apresenta: o Dr. Sebastião é sobrecarregado no trabalho, é solitário, não se exercita, não possui animais e nem momentos de lazer, alimenta-se de fast-food etc. Nesse sentido, as ilustrações carregam uma crítica social à vida contemporânea baseada na alienação do trabalho, que está omitida no discurso narrativo, mas muito presente no icônico. Tal dicotomia (tempo cronológico $x$ tempo psicológico) se deixa transparecer nas ilustrações seguintes: enquanto o vizinho toma, sozinho, o seu café e lê o jornal matinal (fig. 4), o avô, em atitude subversiva à seriedade do dia-a-dia, faz aviõezinhos de papel para divertir o neto, que olha para o "brinquedo" com encantamento:

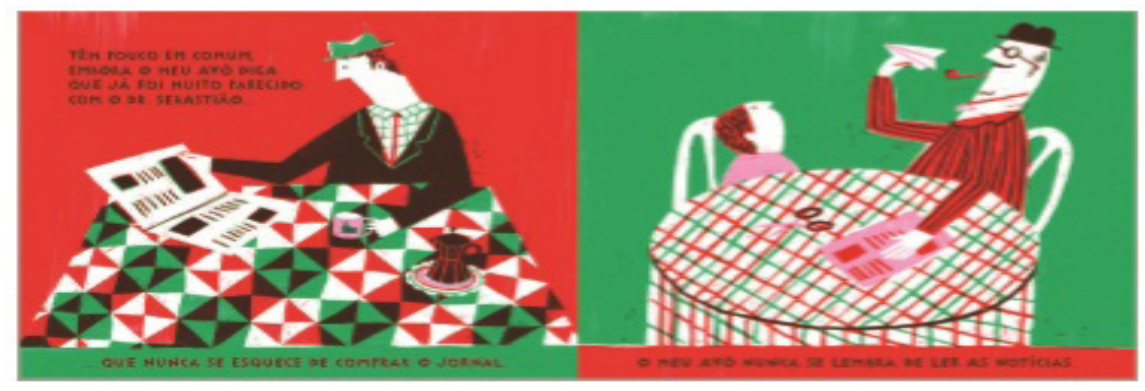

Figura 4 - O avô versus Dr. Sebastião

have missed while trying to get a full understanding of the plot in the first reading" (COLOMER, KÜMMERLING-MEIBAUER E SILVA-DÍAZ, 2010, p. 116) 
O bom aproveitamento do tempo pelo avô é, textualmente e imageticamente, descrito no livro, enquanto que a certo momento somente as imagens revelam as atividades do Dr. Sebastião. O narrador empenha-se em contar, unicamente através do discurso, o dia-a-dia do avô. As ilustrações referentes ao Dr. Sebastião, agora sem a legenda, passam a exigir a atenção do leitor, visto que o texto visual passa a deslocar várias informações para as imagens, aprofundando-o, ampliando as possibilidades da história e complicando o enredo (RAMOS, 2010, p. 31).

O texto verbal está, portanto, longe de encerrar os sentidos do livro ilustrado, sentidos esses que só podem ser percebidos em completude através da apreciação de toda a obra, dos elementos textuais e paratextuais. Muitas são as atividades do avô descritas verbalmente pelo neto-narrador e ilustradas pelas imagens: aulas de alemão e pilates; piqueniques na relva; jardinagem; escrita de cartas de amor; discussões sobre artes; viagens à Paris (por vias de leitura, como nos apresenta unicamente a ilustração); chá da tarde com amiga; confecção de massas italianas; ajuda aos pugs na travessia da rua; busca do neto à escola; novo cruzamento com o Dr. Sebastião etc. Todavia, grande parte da jornada diária do avô é cumprida junto do neto.

O referido livro demonstra que a realidade do idoso, diferentemente da realidade do adulto producente, pode se aproximar mais do ideário infantil, ao dispor de tempo para atividades que não se esgotam no cumprimento de responsabilidades laborais, pois permitem a partilha, o afeto e a dinamicidade requeridos pelo cotidiano de uma criança. A disposição do tempo é representada como fio condutor dos afetos e das relações intergeracionais. Faz-se oportuno saudar a abordagem do tempo nessa obra infantil, uma vez que sua presença é sutilmente posta, fazendo-se perceber, mas abstendose de juízos de valor ao estilo de vida de uma personagem ou outra. Ao registrar a importância do tempo para os parentes, a ilustração que encerra a obra traz uma carga bastante afetiva:

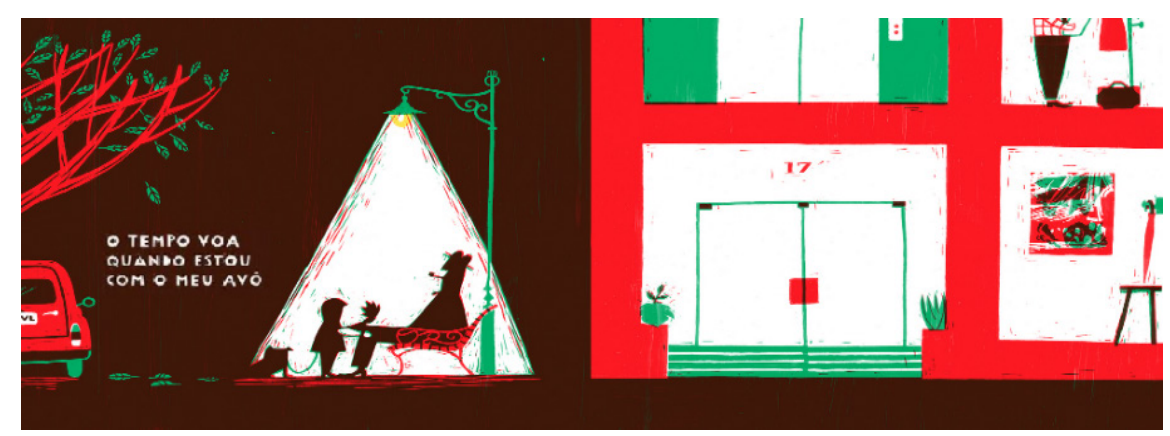

Figura 5 - A afetividade entre avô e neto

Em análise à crítica à vida contemporânea, percebemos: um prédio (construção do homem), imponente, que ocupa toda a direita da folha dupla, em oposição à árvore (natureza), que se desfolha, em alusão ao tempo que se esgota - e aparece timidamente à esquerda; uma grande porta fechada (prisão), em oposição ao cenário aberto (liberdade) e à luz que ilumina avô e neto; o Dr. Sebastião 
(reconhece-se pela mala), no primeiro andar, ilustrado da cintura para baixo, em oposição aos parentes que conversam ao ar livre; o papel (produto fabricado), que o Dr. Sebastião segura, em oposição à folha (produto natural) que mostra ou presenteia o neto ao avô; a mala (trabalho e responsabilidade), aos pés do homem, em oposição ao bichinho de estimação (descontração) aos pés dos parentes. Notese que o espaço, anteriormente destinado às "legendas" das ilustrações, aparece agora vazio. Apesar da frase carinhosa do neto-narrador sobre os momentos com o avô, "O tempo voa quando estou com o meu avô", o amor é explicado através das oposições observáveis na ilustração da folha dupla, indicando cumplicidade e afetividade entre avô e neto.

As guardas (fig. 6) da obra, por sua vez, também sinalizam o esgotamento (tanto do tempo cronológico como do próprio livro), pois fazem uma clara alusão ao tempo disposto (na presença da cor vermelha que, como já mencionado, representa ambientes agitados), no início do dia, e ao tempo esgotado (retratado pela ausência da cor vermelha e presença da cor branca), dos parentes, ao cair da noite. Nada mais precisa ser dito.

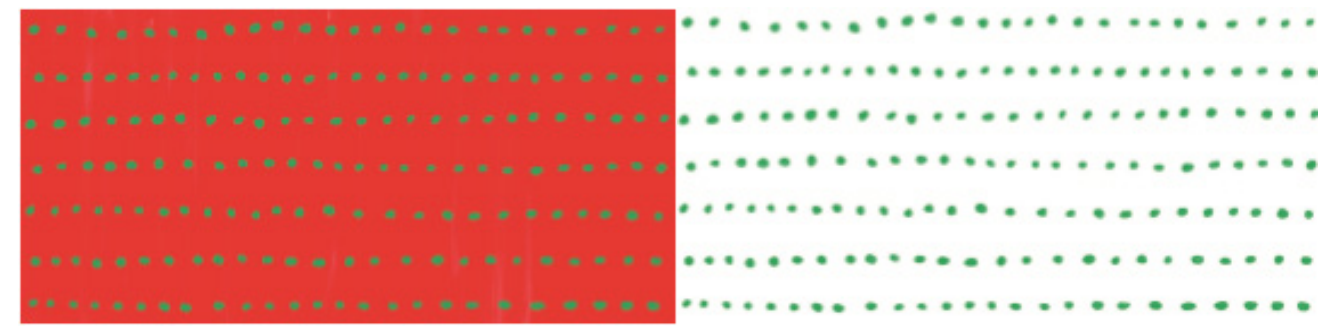

Figura 6 - O tempo nas guardas de $O$ meu avô (2014)

Tal como na obra de Sobra, a seguir analisamos a representação literária de uma avó que também valoriza os momentos com a neta. Essa valorização vai além do sentido epistemológico - dar valor, importância, pois esse reconhecimento de valor é perpetuado não somente por ações momentâneas, mas por fotografias que têm como função manter a memória viva.

\section{Brasil}

O livro Vó, para de fotografar! (BRENMAN \& KARSTEN, 2018), traz uma relação muito contemporânea entre avó e neta. De tamanho grande e lembrando um álbum de fotografias, a capa é alegre; possui o fundo escuro e retrata uma senhora de cabelos brancos e corte moderno, que ocupa toda a ilustração (fig. 7): 


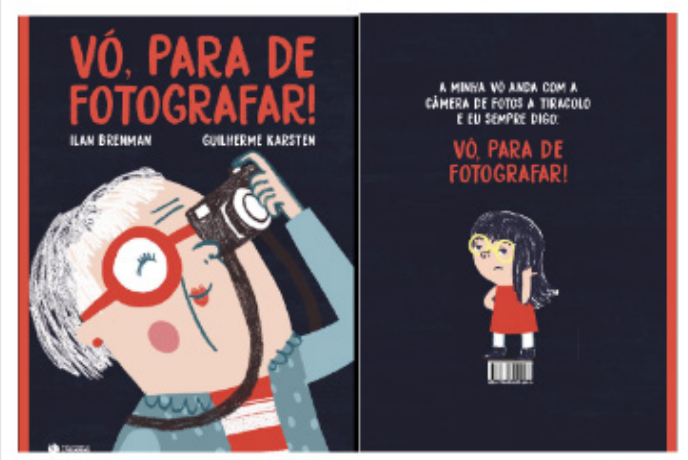

Figura 7 - Capa e contracapa de Vó, para de fotografar (2018)

A personagem segura uma máquina de fotografar junto ao rosto, mantém um dos olhos fechados e o outro na lente. Ela parece estar procurando o melhor foco de algo que está levemente acima dela; usa óculos vermelhos, a mesma cor do título do livro no alto da capa. Pode-se inferir, já a partir da leitura da capa e contracapa, que essa pessoa se trata de uma avó, no entanto, é notável o seu toque jovial, pois os óculos vermelhos combinam com a sua maquiagem - batom e blush, da mesma cor. A sua vestimenta sugere um estilo muito jovem, de cores vibrantes que no senso comum não são muito usadas por pessoas idosas. Na contracapa (fig. 7), em contraste com a senhora ilustrada em tamanho grande, uma menina pequena é retratada. A sua feição emburrada, percebida pela expressão dos olhos e pela mão na cintura, sugere o aborrecimento típico da adolescência. A menina usa um vestido vermelho e óculos amarelo. O texto, acima da ilustração da garota, poderia ser atribuído como uma fala dela, pois está escrito: “A minha avó anda com a câmera de fotos a tiracolo. E eu sempre digo: Vó, para de fotografar!"

As guardas da obra (fig. 8), tanto iniciais quanto finais, são compostas por óculos das cores vermelho (que remetem à avó) e amarelo (rememorando a menina). É possível perceber, nos óculos, olhos diferentes e as expressões também aludem para sentimentos diferenciados, pois os olhos do óculos vermelho, embora fechados, representam expressão de entusiasmo, carinho e alegria e os dos óculos amarelos, o tédio e o possível descontentamento. O leitor, quando estimulado por um mediador mais experiente, poderá perguntar “de quem são esses olhos?”, “como será a relação dessas duas pessoas, visto que seus olhos expressam sentimentos tão diferentes?" 


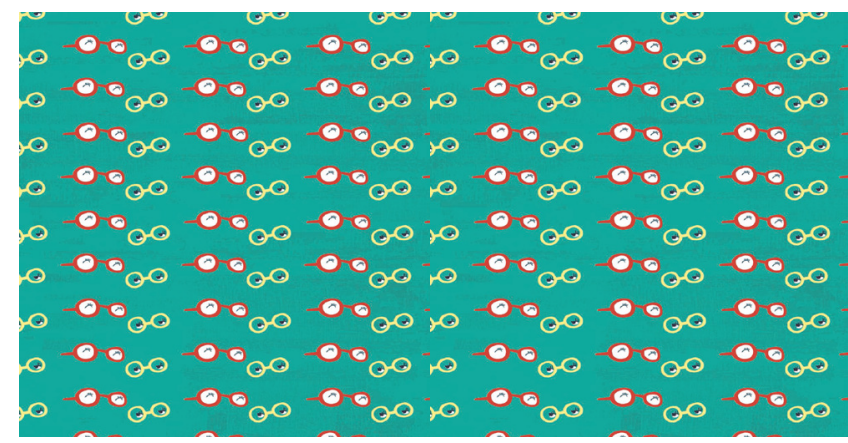

Figura 8 - Elementos afetivos nas guardas de Vó, para de fotografar (2018)

De significado ainda pouco conhecido para o leitor, esses óculos guardam certo mistério e se constituem, ao mesmo tempo, como elementos simbólicos (de afetividade, visto que são objetos que aproximam as personagens) e convidam à leitura. Todavia, caso a criança leitora tenha prestado atenção nos paratextos da capa e contracapa, poderá responder sobre os óculos vermelhos como sendo da senhora "moderninha" e os óculos amarelos como sendo da menina mal humorada.

A capa interna também é bastante interessante, pois quase sua totalidade é tomada pelo título da obra, nomes do autor e ilustrador, dedicatórias dos mesmos para as suas avós e, na parte inferior dessa folha de rosto, há uma mão clicando uma máquina fotográfica, aparentando que uma foto do leitor está sendo tirada rapidamente, para que esse não perca o seu momento de leitura e se sinta parte integrante e importante dessa história. Novamente, esse elemento simbólico representa convite e afeto.

A narrativa inicia-se na voz da criança e o livro aberto reapresenta as duas personagens da capa. Na página simples da esquerda, aparece a menina, idêntica à contracapa, bem como a reescrita do texto verbal: "A minha avó anda com a câmera de fotos a tiracolo. E eu sempre digo:” (p. 4). Olhando para a página da direita, temos a avó, agora de corpo inteiro, usando tênis, vestido, casaquinho e com a máquina fotográfica em um dos olhos, tirando uma foto. Percebemos, portanto, que as inferências feitas a partir da leitura dos paratextos se confirmam, pois agora podemos atribuir às personagens uma relação familiar, trata-se de uma avó e uma neta.

A história continua contando diversos momentos em que a avó estava a fotografar a neta: na festa a fantasia, a avó ficou de ponta cabeça para fotografar, o que despertou olhares de outras crianças (fig. 9); na apresentação de dança da menina, não só fotografou como deu tchauzinho e fez com que a neta ficasse brava e envergonhada (compreensível pela ilustração da expressão da neta); no jogo de handebol também provocou olhares do público; no zoológico se pendurou na árvore, junto do macaco, para tirar a foto; durante o banho relaxante de espuma da neta; na pizzaria com a família e até no trem fantasma do parque de diversões a avó tirou foto, o que fez com que os monstros da atração ficassem confusos. 


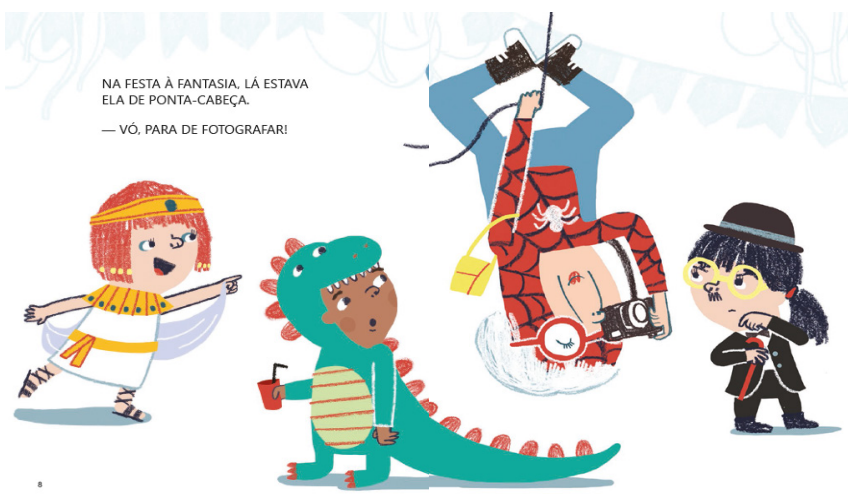

Figura 9 - Festa a fantasia

Em todas essas situações, faz-se claro que a neta reage de uma forma negativa, sempre respondendo "vó, para de fotografar!" e suas expressões variam entre brava, cansada, assustada, envergonhada e entediada. Os momentos em que a avó, personagem sem um nome próprio, fotografa a neta são de atividades em família, como na pizzaria ou no aniversário da prima, ou afazeres extracurriculares, como apresentação de dança e o jogo de handebol. Há ainda momentos prazerosos de passeios no zoológico e no parque de diversões, ou aqueles instantes em que se espera alguma privacidade para a neta, como é o caso do banho de espuma. No entanto, a avó está sempre presente e o texto visual, às vezes, a coloca de corpo inteiro, fotografando, ou meio corpo e até mesmo somente o braço que segura a câmera fotográfica.

Note-se que, tal como no livro de Sobral, o Vó, para de fotografar também demonstra lograr de avanços no contexto editorial e novas técnicas de design que conferem identidade e qualidade às suas ilustrações. Ambos trazem, inclusivamente, jogos cromáticos (nas cores vermelha e verde), icônicos (grande x pequeno) e ângulos (perto x longe) bastante parecidos. A cor amarela aparece sutilmente em ambas as obras, numa espécie de "quebra" dos jogos cromáticos e, ao mesmo tempo, da ideia da agitação das atividades, sugerindo amizade entre as personagens de parentesco.

Os jogos verbais, como os paralelismos e repetições, bastante comuns em textos infantis, também aparecem em ambos os livros. Entretanto, na obra de Brenman, em que a cada mudança de atividade/página a neta repete "Vó, para de fotografar!", o recurso verbal da repetição aparece com mais força, estimulando no leitor, a todo tempo, inferir sobre qual será a ação ou o lugar que a vovó fotógrafa vai estar ao passar a página. Neste sentido, verificamos que os jogos verbais e os jogos icônicos se complementam, a fim de gerar expectativas e ludicidade para o leitor; dinamicidade e novos significados para a narrativa.

Ao voltarmos as nossas atenções para as expressões faciais das personagens, observamos que as feições da neta são típicas da criança em puberdade, quando a identidade está em plena formação. De acordo com a psicologia, quando as crianças estão crescendo e entrando na adolescência é comum sentirem vergonha dos mais velhos, sobretudo em locais públicos (BILCHES, 2019, s/n) como é o 
caso da neta da obra ora analisada. A garota demonstra, sobretudo através do texto visual, vergonha e aborrecimento para com a avó, o que pode ser uma confirmação de não se sentir segura nos ambientes em que as ações de fotografar acontecem ou, ainda, uma ausência de pertencimento. Amparo, Alves e Cardenas (2004), explicam esse fenômeno:

A identidade organiza-se na confluência do individual e do social, portanto, implica o próprio eu (self) e o outro nas suas várias representações como a família, os pares, as instituições e a comunidade. A noção de identidade relaciona-se, nesse sentido, ao pertencimento e, portanto, tem um caráter ao mesmo tempo individual estrutural (quando ligado à apropriação do corpo próprio, representação de si e imagem do corpo) e social, quando relacionada às dimensões de vinculação ao outro e territorialização. (p.12-13)

Dessa maneira, ao retomarmos à relação entre avó e neta no livro infantil de Brenman, podemos verificar que somente ao final da história, quando a neta vai passar a noite na casa da avó e constata a idosa pensando e olhando as fotos tiradas durante a narrativa (fig. 10) é que as expressões de ambas mudam:

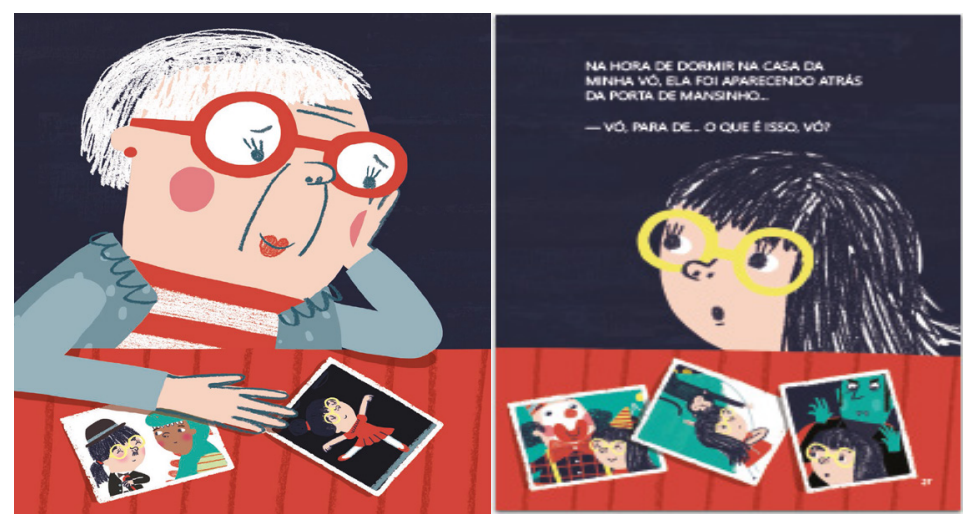

Figura 10 - Expressões de afetividade

Em contraste com as expressões de entusiasmo (por parte da avó) e de aborrecimento (por parte da neta), durante toda a narrativa, temos, respectivamente, expressões de tristeza e surpresa. Ao olhar as fotos da neta, a avó, de olhos baixos, sobrancelhas arqueadas e rosto apoiado num dos braços, parece angustiada com a ideia de atender ao pedido constante da sua ente: parar de fotografar. A neta, ao se deparar com o sofrimento da avó, apresenta um semblante surpreso que pode ser percebido pelos olhos arregalados e o formato de sua boca em "o". A surpresa da neta está, provavelmente, relacionada à compreensão da importância que o ato de fotografar tem para a sua avó.

Ao virarmos a página, o leitor é, por sua vez, surpreendido com a fala da menina para a avó, que afirma: “-Vó, não para nunca de fotografar! Eu te amo muito!” (p.29): 


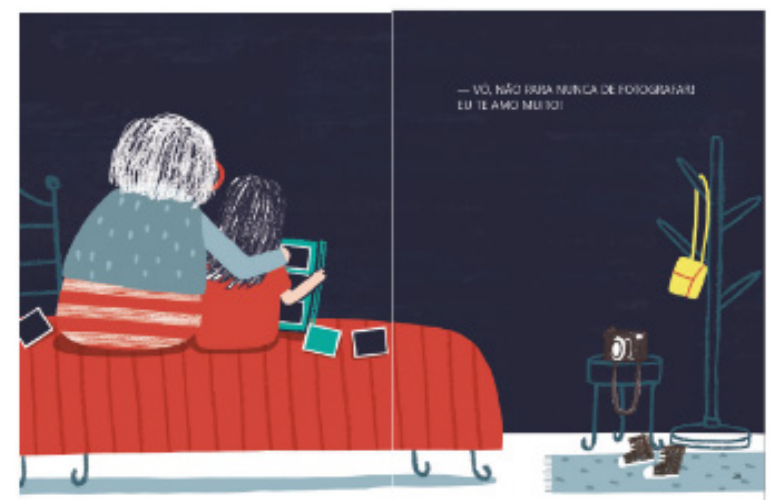

Figura 11 - Álbum de fotos

A ilustração (fig. 11) mostra as duas de costas, abraçadas, apreciando as fotos tiradas no decorrer da narrativa, em um grande álbum. A reação da menina ao pedir para que a avó não mude seu jeito de ser, além de nos revelar empatia, nos remete, ainda, à citação anterior, na qual certifica o laço social, tanto familiar quanto afetivo, que há entre as duas (avó e neta) e à construção de uma identidade particular, pois a neta agora compreende o significado da ação de fotografar para a idosa.

Novamente, temos a função social do velho, referendada por Bosi sobre a memória. Para a avó da história, fotografar e guardar na memória o crescimento da sua neta, os momentos vivenciados com ela, é tê-la presente em todos os outros em que não estão juntas. Dessa maneira, as páginas finais do livro mostram ao leitor uma transformação nos sentimentos das personagens, uma relação de afetividade entre a velha e a menina. A senhora se mostra disposta a fazer com que momentos, algo abstrato, se transformem em algo concreto, as fotos. Percebemos, portanto, que é através da fotografia que a avó procura guardar as memórias com sua neta e, assim, se coloca em posições e situações inusitadas. É-nos compreensível que isso aconteça, pois, ao envelhecer, o indivíduo volta o olhar a si: O que fez? Quais relações construiu? O que pode gerar certo anseio e fazer com que ele queira aproveitar todos os bons momentos da vida?

\section{Considerações finais}

Muitas são as similitudes no que tange as representações do idoso e das relações intergeracionais abarcadas pelos livros ilustrados O meu Avô, de Catarina Sobral (2014), e Vó, para de fotografar!, de Ilan Brenman \& Guilherme Karsten (2018).

Dentre os elementos paratextuais, destacam-se as capas (de tamanhos e cores específicas que coadunam para o sentido geral da obra), contracapas (que propõem jogos cromáticos com as capas), guardas (em que as cores denunciam a ambientação das narrativas e as ilustrações facilitam 
a inferência dos leitores na entrada ao livro) e folhas de rosto (com os seus elementos simbólicos e sugestivos que convidam o leitor a passar a página e seguir a leitura) etc.

Dos elementos textuais, sobressaem: a omissão dos nomes dos idosos, a repetição de certas sentenças, bem como as frases de encerramento das obras, proferidas pelos netos-narradores (" $\mathrm{O}$ tempo voa quando estou com o meu avô", para a primeira obra, e "Vó, não para nunca de fotografar! Eu te amo muito!", para a segunda).

Já entre os elementos icônicos, por sua vez, encontram-se: a presença dos símbolos afetivos (o avião de papel e o relógio, no caso da primeira, e os óculos e a máquina de fotografar, no caso da segunda); as expressões faciais de contemplação entre avôs e netos (o olhar admirado do neto para o avô, na capa da primeira; a expressão de carinho da avó ao fotografar a neta, na segunda); o exercício da empatia, ao se colocarem, netos e avôs, no lugar do outro (quando o neto usa os óculos do avô, experimentando a sua dificuldade em observar, no caso da primeira obra; quando a neta passa a compreender a importância do ato de fotografar para a avó, no caso da segunda) etc. No caso específico das obras analisadas, a interação dos referidos elementos é fundamental para a compreensão de uma experiência humana de natureza afetiva: a relação intergeracional entre avôs e netos. Ressalta-se ainda a importância da memória em ambos os textos literários, pois o exercício de lembrar, rememorar a rotina dos netos com avós é essencial para ativar e valorar uma memória em construção.

Avós, os protagonistas idosos dos referidos livros ilustrados apresentam diferentes gêneros, comportamentos e atividades diárias. Nesse sentido, as obras sinalizam a heterogeneidade da velhice, ao mesmo tempo em que possuem, ambas as personagens, corpos e mentes sadias, uma certa jovialidade, vidas ativas e dedicadas a tutelar os seus netos. É justamente através dessa função social do cuidar, tão relacionada aos vínculos familiares e às questões afetivas, que são apresentadas as relações intergeracionais de cordialidade e cumplicidade entre as personagens avós e netos, contribuindo para a formação literária e reminiscente de seus leitores.

\section{Referências}

AMPARO, A. M. d; ALVES, P. B.; CARDENAS, C. J. Pertencimento e identidade em adolescentes em situação de risco de Brasília. Rev. Bras. Cresc Desenv Hum, São Paulo, 14(1), 11-20, 2004.

ARIZPE, E. \& STYLES, M. Children reading picturebooks: interpreting visual texts. New York: Routledge, 2016.

BRENMAN, I. \& KARSTEN, G. Vó, para de fotografar!. 1 ed. São Paulo: Editora Melhoramentos, 2018. 
BILCHES, W. Por que adolescentes às vezes sentem vergonha dos pais. Gazeta do Povo. Sempre família. 9/7/2019.

BOSI, E. Memória e Sociedade: lembranças de velhos. São Paulo: Companhia das Letras, 1994.

BOON, M. Y. \& DAIN, S. J. The development of color vision an the ability to appreciate color in picturebooks. In: KÜMMERLING-MEIBAUER, B; MEIBAUER, J; NACHTIGÄLLER K \& ROHLFING, K. J. Learning from Picturebooks: perspectives from child development and literacy studies. New York: Routledge, 2015.

CARDOSO, D. M. A relação texto e imagem na criação do livro-álbum: o caso de Catarina Sobral. Dissertação de Mestrado em Estudos Literários. Universidade de Aveiro, 2017.

COLOMER, T; KÜMMERLING-MEIBAUER, $\quad$ B. $\quad \& \quad$ SILVA-DIAZ, $\quad$ C. $\quad$ (Eds.). New directions in picturebook research. New York and London: Routledge, 2010.

CULLER, J. The Closeness of Close Reading. V 152, No 1. ADE Bulletin, 2012.

DIOUF, S. As tranças de Bintou. São Paulo: Cosac \& Naify, 2004.

FERNANDES, C. R. D. Avós e netos na literatura infantil: vidas compartilhadas. Educ. Real., Porto Alegre, v. 38, n. 4, p. 1089-1112, Dec. 2013. Available from <http://www.scielo.br/scielo.php?script=sci_arttext\&pid=S217562362013000400005\&lng=en\&nrm=iso $>$. access on 02 Apr. 2020. https://doi.org/10.1590/S2175-62362013000400005.

FOX, G. ; GIRARDELLO, G. A narração de histórias na sala de aula. In: GIRARDELLO, Gilka (Org.) Baús de chaves da narração de histórias. 4a . Ed. Santa Catarina: SESC, 2008.

LETRIA, J. J. \& LETRIA, A. Avô, conta outra vez. Porto: Âmbar, 2008.

LOBATO, M. Histórias de tia Anastácia. 5ed. São Paulo: Editora Brasiliense, 1956.

LOBATO, M. Reinações de Narizinho. São Paulo: Globo, 2009.

MATOS, G. A. A palavra do contador de histórias: sua dimensão educativa na contemporaneidade. São Paulo: Martins Fontes, 2005.

MENDES, T. M. S. Da adolescência à envelhecência: convivência entre as gerações na atualidade. Porto Alegre: Mediação, 2012. 
PRADO, D. O que é família?. Coleção Primeiros Passos. São Paulo: Brasiliense, 2017.

RAMOS, A. M. Literatura para a infância e ilustração. Leituras em diálogo. Porto: Tropelias \& Companhia, 2010.

SILVEIRA, R. Velhice e morte na literatura para crianças: apontamentos sobre o que e como se ensina a elas. ANPED, 2012. Disponível em: http://www.ucs.br/etc/conferencias/index.php/anpedsul/9anpedsul/paper/viewFile/2977/234 Acesso em: 02. Abr. 2020.

SOBRAL, C. O meu avô. Lisboa: Orfeu Negro, 2014. 